\title{
REDESIGN PRODUK PECI MENGGUNAKAN METODE KANSEI ENGINEERING
}

\author{
Saeful Najib, Ida Betanursanti \\ Program Studi Teknik Industri \\ Sekolah Tinggi Teknologi Muhammadiyah Kebumen \\ saefulnajib@gmail.com
}

\begin{abstract}
Peci is one of the typical Indonesian fashion products favored by men. Peci used for a purpose both official and unofficial purposes. Many people want a product that is more than the usual Peci both in terms of materials and motifs. The purpose of this study is to realize the expectations of customers and develop the better design of peci that fit to the customer's feelings. The method used in this study is Kansei Engineering. That is a method that uses image or feeling psychologically from the user of the product. Then observations is looking for Kansei words and samples of product, There are obtained 10 Kansei words that represent the feeling of customers and 5 sampels of products of craftsmen. Then conjoint analysis is use to get the value of the relationship between elements design and Kansei words. The results of conjoint analysis obtained that special Peci is peci with batik embroidery motif with price is Rp35.000,00 and made of quality velvet. That is the highest preference of most favored by respondents. Recommend the design of the peci that has been obtained is with first quality velvet, batik embroidery three-leaved vines, Lidded green six cmyk: 100, 0, 100, 0 velvet, black cmyk: 0,0,0, 100 Flowers, red cmyk: 0,100,100,0. Ventilated at the top with a semicircular, and use the cardboard inside the furing wrapped with satin lining.
\end{abstract}

Keywords: Kansei engineering, Peci design, conjoint analysis

\section{PENDAHULUAN}

\section{A. Latar Belakang}

Industri busana di Indonesia saat ini berkembang pesat, baik busana pria maupun wanita. Begitu juga dari segi busana muslim, di Indonesia busana muslim berkembang dengan sangat pesat bahkan paling maju di dunia. Pelengkap busana muslim pria dikenal dengan peci atau songkok. Peci merupakan busana asli Indonesia, menurut sejarahnya peci bisa terkenal seperti saat ini karena Presiden pertama Indonesia dan banyak faktor lain. Semakin banyak permintaan akan peci di Indonesia maka banyak industri berlomba untuk memenuhi kebutuhan tersebut. Salah satu kota penghasil peci terbesar di Indonesia adalah Kebumen tepatnya di Desa Bandung Kecamatan Kebumen dan Desa Bojongsari Kecamatan Alian. Di daerah ini dapat ditemukan banyak home industry yang memproduksi peci, selain tas dan celana. Dari berbagai home industry yang memproduksi peci, berdasarkan observasi yang dilakukan di pengrajin peci kebanyakan peci yang dihasilkan sama modelnya antara satu dengan yang lainnya, ratarata model yang dihasilkan oleh pengrajin peci ada lima sampai enam model, terdiri dari berbagai jenis bahan. Untuk memperluas penjualan produk peci yang saat ini hanya dijual berdasarkan permintaan kerabat yang ada di luar kota, dan hanya dijual berdasarkan pesanan model tertentu, diperlukan penelitian tentang permintaan modelmodel atau jenis-jenis peci yang paling diminati oleh konsumen.

Penelitian sebelumya dilakukan oleh Siti Muntahanah dan Tjahjani Murdijaningsih (2014) tentang tinjauan kinerja manajerial dari aspek keuangan pada usaha kecil menengah (UKM) home industry peci di Desa Bandung Kebumen, dan Moh. Fatkhul Mujib (2010) tentang analisis faktor-faktor yang berpengaruh secara langsung terhadap kinerja usaha kecil dan menengah.

Berdasarkan informasi dari para pengrajin yang ada di Desa Bandung Kecamatan Kebumen dan Bojongsari Kecamatan Alian, selama ini para pengrajin hanya memasarkan berdasarkan permintaan dan tidak mengetahui model peci yang diminati 
oleh konsumen. Sehingga perlu dilakukan penelitian tentang desain produk peci yang diminati oleh konsumen khususnya di daerah Kebumen.

\section{B. Tujuan Penelitian}

Tujuan penelitian untuk:

a. Mengetahui desain peci pengrajin yang paling disukai oleh konsumen.

b. Mengusulkan redesain peci kepada pengrajin berdasarkan perferensi masyarakat terhadap produk peci.

\section{LANDASAN TEORI}

\section{A. Kajian Pustaka}

Penelitian produk brassiere menggunakan Kansei engineering menurut Caecilia Sri Wahyuning, Arie Desrianty, dan Rika Rahmawati (2011) tentang tuntutan konsumen terhadap suatu produk yang semakin kompleks menyebabkan perlunya dilakukan perancangan produk yang berorientasi pada konsumen/ pengguna. Dalam pemilihan suatu produk sampai keputusan pembelian, konsumen dipengaruhi oleh emosi dan perasaan, sehingga hal ini sebaiknya menjadi bahan pertimbangan bagi para perancang ketika akan merancang suatu produk. Brassiere, sebagai produk yang digunakan oleh para wanita, memerlukan rancangan konsep produk bra yang disesuaikan dengan aspek-aspek emosional yang dirasakan penting sehingga dihasilkan suatu rancangan produk brassiere yang sesuai dengan kebutuhan mereka. Kansei Engineering Method merupakan suatu metode yang menggunakan image atau feeling secara psikologis dari pengguna terhadap suatu produk untuk digunakan dalam merancang suatu produk, sehingga dengan menggunakan metode ini produk brassiere yang dihasilkan dapat memenuhi kebutuhan emosional para wanita. Berdasarkan penelitian diperoleh 6 konsep produk brassiere, sehingga dapat digunakan dan diimplementasikan, dengan tetap menyesuaikan terhadap kondisi pasar (trend) yang ada dan keterbatasan yang dimiliki oleh perusahaan dalam proses manufaktur produk brassiere.

Penelitian menurut Mei Haryono dan Choirul Bariyah (2014) menyatakan bahwa pada produk yang berupa alas kaki (sandal pria) dapat diidentifikasi belum adanya upaya dari produsen/perajin alas kaki untuk melakukan penelusuran terhadap harapan dan keinginan konsumen akan produk alas kaki yang sesuai dengan perasaan psikologis konsumen. Di sisi lain kesadaran dan keinginan konsumen akan desain produk semakin meningkat. Penelitian ini berusaha untuk mengetahui citra atau harapan konsumen akan produk alas kaki yang berupa sandal pria melalui pendekatan emosional dan psikologis, sehingga dapat dilakukan perancangan dan pengembangan produk alas kaki yang sesuai dengan citra dan harapan mereka. Metode Kansei Engineering digunakan untuk memformulasikan rancangan produk alas kaki berdasarkan perasaan psikologis konsumen yang tercermin melalui kata kansei. Kuesioner yang digunakan pada metode Kansei Engineering ini adalah kuesioner elemen desain dan kuesioner semantic differential. Model Kano digunakan untuk memetakan atribut-atribut produk berdasarkan perfomansinya. Hasil akhir penelitian ini adalah dengan mengintegrasikan kedua metode tersebut sehingga diketahui bahwa desain yang sesuai dengan citra/image dan perasaan psikologis konsumen adalah desain dua kategori Kano, yaitu one dimensional dan indifferent.

Penelitian menurut Margaretha Srikandi W. Johan K. Runtuk Lusia Permata Sari H (2011) tentang rekayasa desain Batik Tulis Jetis Sidoarjo melalui implementasi Metode Kansei Engineering. Sebagai produk seni yang diminati banyak orang, desain batik tidak hanya harus bercitarasa seni tinggi, tetapi juga harus sesuai dengan ekspektasi pelanggan. Oleh karena itu, ketika seorang desainer batik mulai merancang desain baru, ia mengintegrasikan banyak permintaan berdasarkan prospektif pelanggan; tidak hanya permintaan teknis dan objektif, tapi juga estetika emosional, informasi dan 
inspirasi. Hasil penelitian, didapatkan nilai resquare untuk model regresi yakni sebesar 45,5\% dimana veriabel pertama pembentuk model regresi ialah menarik perhatian dengan koefisien 0,674. Selanjutnya dari hasil analiysis kruskal-willis didapatkan karakteristik desain batik tulis Jetis yang baru yakni: (1) motif : geometris, (2) ornamen utama : kembang 2, (3) ornament pengisi : lung- lung an, (4) jumlah isen : 3, (5) warna primer : kuning, (6) warna skunder : coklat, (7) ada lis, (8) material kain : primis.

Menurut Anitawati Mohd. Lokman (2011) menyatakan bahwa dewasa ini tren dalam pengembangan produk menunjukkan bahwa masukan dari konsumen perlu aspek teknis desain produk yang akan menentukan keberhasilan mereka di pasar. Kebutuhan eksplisit jelas dan mudah untuk digambarkan namun, kebutuhan implisit seperti pengalaman emosional sulit untuk diukur. Penelitian ini memperkenalkan metode dan teknik yang dapat digunakan untuk mengetahui kebutuhan konsumen secara umum dan secara khusus. Kerangka kerja ini menawarkan pemahaman yang cepat dan mudah dalam pelaksanaan Kansei Engineering untuk menemukan kebutuhan implisit konsumen dan analisis hubungan untuk desain produk.

Penelitian menurut Vonny Setiaries Johan dkk. (2012) tentang pengembangan produk sangat penting bagi produsen untuk mengetahui keinginan pelanggan terhadap produk. Penelitian ini menggunakan metode evaluasi desain produk dengan menggunakan metode Kansei engineering dan pendekatan aturan asosiasi. Sebagai objek penelitian digunakan kursi makan rotan, desain kursi dibagi menjadi lima unsur yaitu sandaran tangan, anyaman, sandaran punggung, dudukan, dan desain kaki. Dalam penelitian tersebut Kansei words dari customers seperti indah, unik, inovatif, nyaman, kokoh, sederhana, dapat diterjemahkan dalam desain elemen dengan menggunakan nilai dukungan dan kepercayaan diri, sehingga aturan dapat digunakan sebagai dasar untuk penilaian kursi makan rotan.

Menurut Wakhid Agung Guna Ady (2011), penelitian dilakukan dengan mengembangkan desain kursi roda pada lansia berdasarkan citra (image) menggunakan metode Kansei engineering. Semakin berkembangnya zaman, konsumen menghendaki produk yang mempunyai multifungsi. Dengan mengubah objek penelitian kursi roda yang standar menjadi kursi roda yang dapat digunakan dalam berbagai kegiatan. Hasil dari penelitian tentang kursi roda ini kerangka dari besi, sistem penggerak yang otomatis, memiliki sarana pendukung berupa pispot, bahan sandaran woven polyster dan warna polos.

\section{B. Dasar Teori}

Istilah Kansei berasal dari bahasa Jepang, yang secara umum berarti "Psychological feeling or image of product" atau gambaran perasaan psikologis terhadap suatu produk. Tujuan dari kajian studi Kansei adalah untuk mengetahui struktur emosi yang hadir dalam perilaku manusia. Struktur ini dikenal dengan Kansei seseorang. Sementara itu, dalam kajian studi desain, Kansei merupakan elemen yang penting yang mendorong seseorang untuk menghantarkan keinginan dalam menciptakan suatu karya yang besar. Kansei engineering merupakan jenis teknologi yang menerjemahkan perasaan pelanggan kedalam spesifikasi desain. Usia Industri bergantung pada sebuah produk, dan konsep pasar mengenai pengembangan produk baru. Pada tahun 1970-an, produsen menghasilkan produk dan orang-orang membelinya. Pada saat itu, produsen merancang produk melalui konsep mereka sendiri. Namun, konsumen harus membeli mereka terlepas preferensi pribadi. Para konsumen yang pintar berkeinginan bahwa produk harus sesuai dengan perasaan mereka sendiri baik itu desain, harga dan fungsi. (Nagamachi, 1995).

Emosi menurut Damasio (1999) adalah antitesis/ kebalikan dari logika. Unsur emosi dalam diri manusia berbeda dengan perasaan. Perasaan menghubungkan aspekaspek fisik dan berada dalam tataran tingkat kesadaran yang lebih rendah. Terdapat dua macam perasaan/ feeling, yaitu internal feeling dan external feeling. Internal feeling 
adalah perasaan yang berkaitan dengan masalah fisik, sedangkan external feeling adalah perasaan yang berhubungan dengan aspek sosial. Emosi dipandang jauh lebih subjektif dan lebih kompleks dari pada perasaan.

\section{METODOLOGI PENELITIAN}

\section{A. Pengumpulan Data}

Sebelum mengumpulkan data-data yang diambil dari berbagai sumber, perlu diketahui dalam penelitian ini menggunakan Jenis kansei 1 atau tipe klasifikasi kategori.

Pengumpulan Data terdiri dari:

\section{Penentuan Domain}

Penentuan domain merupakan awal dalam melakukan penelitian. Tujuan penentuan domain untuk membuat spesifikasi produk yang akan diteliti atau dirancang, meliputi penentuan domain sendiri yang terdiri dari penentuan spesifikasi produk, pasar, dan grup target.

\section{Pengumpulan Kansei Words}

Kansei words merupakan kata-kata yang dikumpulkan berdasarkan sumber yang dapat mewakili dan menggambarkan domain produk. Kata kansei bisa didapatkan dari observasi atau wawancara, majalah, internet, dan jurnal. Kansei words dapat berupa kata sifat, kata benda, kata kerja dan terkadang kalimat; seperti cantik, elegan, premium, cerdas, sederhana, besar, penuh warna, merah, biru, kotak, mudah digunakan, dan lainnya (Nagamachi, 2011).

a. Penyebaran Kuesioner Terbuka

Penyebaran kuesioner terbuka dilakukan untuk mendapatkan kata-kata kansei yang diinginkan sesuai dengan image pelanggan tentang sebuah desain peci.

b. Penyusunan Kuesioner Semantik Diferensial (SD)

Kata-kata kansei yang telah didapat kemudian dievaluasi menggunakan semantik diferensial (SD). Semantik diferensial merupakan teknik pengukuran yang diperkenalkan oleh Charles Osgood pada tahun 1957. Pada tahap ini, kansei words yang telah dikumpulkan kemudian dipasangkan dengan lawan dari kansei words tersebut dan diberi skala.

c. Uji Validitas dan Reliabilitas

\section{1) Uji Validitas}

Uji Validitas merupakan uji yang dilakukan untuk mengetahuai valid tidaknya suatu kuesioner, yang digunakan peneliti untuk memperoleh data dari responden. Cara pengujiannya adalah dengan menghitung korelasi antara masing-masing pertanyaan yang menggunakan rumus teknik korelasi product moment sebagai berikut:

$$
r x y=\frac{N \sum x y-\sum \times \sum y}{\sqrt{N \Sigma} x^{2}-\left(\sum x\right)^{2} \sqrt{N \Sigma} Y^{2}-\left(\sum Y\right)^{2}}
$$

Dimana:

$\mathrm{r}=$ angka korelasi

$\mathrm{N}=$ jumlah responden (ukuran sampel)

$\mathrm{X}=$ skor setiap item pertanyaan

$\mathrm{Y}=$ skor total item pertanyaan 


\section{2) Uji Reliabilitas}

Uji reliabilitas adalah uji untuk mengukur sejauh mana alat ukur dapat dipercaya atau dapat digunakan, Ghozali (2009) menyatakan bahwa reliabilitas adalah alat untuk mengukur suatu kuesioner yang merupakan indikator dari peubah atau konstruk. Metode yang digunakan untuk pengujian reliabilitas adalah alpha cronbach menggunakan rumus koefisien:

$$
r_{i}=\frac{k}{(k-1)}\left\{1-\frac{\sum s_{i}^{2}{ }^{2}}{s_{t^{2}}}\right\}
$$

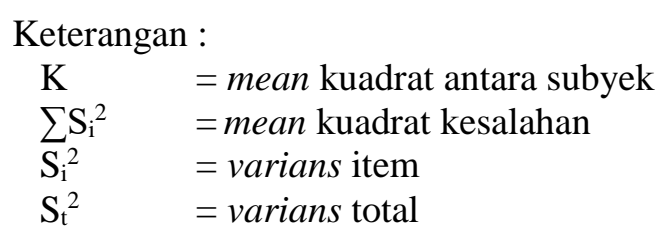

\section{3) Pengumpulan Sampel Produk}

Langkah selanjutnya adalah pengumpulan sampel produk atau desain engineering. Disini peneliti mengambil sampel produk dibeberapa pasar yang berada di sekitar Kebumen dan juga langsung mengambil di pengrajin yang berada di Desa Bandung Kecamatan Kebumen dan Desa Bojongsari Kecamatan Alian.

\section{4) Penentuan Parameter Desain}

Penentuan parameter desain menggunakan Analisis conjoint. Analisis conjoint adalah suatu teknik analisis yang dapat digunakan untuk menentukan tingkat relatif berdasarkan persepsi pelanggan yang dibawa oleh suatu produk tertentu dan nilai kegunaan muncul dari atribut-atribut produk terkait untuk menentukan strategi pemasaran. Berikut ini merupakan fungsi dari analisis conjoint:

a. Mengetahui atribut produk yang disukai konsumen.

b. Membantu menentukan komposisi atribut produk baru.

c. Menganalisis atribut-atribut produk yang sudah diluncurkan ke pasaran, sehingga perusahaan dapat memperbaiki produk tersebut.

Berikut beberapa langkah untuk menerapkan analisis conjoint:

a. Merumuskan masalah

b. Mendesain stimuli dengan menggunakan konsep ortogonalitas dalam mereduksi kombinasi atribut dengan setiap tarafnya.

c. Pengumpulan data dilakukan dengan penyebaran kuesioner pada responden.

d. Melakukan uji validitas dan reliabilitas kuesioner

\section{5) Hasil Rancangan Produk}

Setelah mengetahui keinginan konsumen yang di dapatkan dari tahapan-tahapan uji dalam kansei engineering langkah berikutnya adalah merancang produk yang diinginkan konsumen.

\section{6) Uji Homogenitas}

Uji homogenitas adalah pengujian mengenai sama tidaknya variansi-variansi dua buah distribusi atau lebih. Uji homogenitas varians sangat diperlukan sebelum kita membandingkan dua kelompok atau lebih, agar perbedaan yang ada bukan disebabkan oleh adanya perbedaan data dasar (ketidak homogenan kelompok yang dibandingkan). (Zulkifli Matondang, 2012). Uji homogenitas yang digunkan adalah Uji Marginal Homogenity Stuart Maxwell. Penggunaan 
uji ini untuk melihat apakah terdapat perbedaan atau perubahan antara dua peristiwa sebelum dan sesudahnya. Kategori data yaitu data kategori multinominal lebih dari $2 \times 2$.

\section{HASIL DAN PEMBAHASAN}

\section{A. Penentuan Domain}

Penentuan domain yang dilakukan dalam penelitian ini meliputi:

1. Lokasi penelitian di Kabupaten Kebumen

2. Responden yang diberi kuesioner yaitu usia 15 tahun ke atas

3. Produk peci yang diteliti sebagai sampel berasal dari Pengrajin peci yang berada di daerah Bandung kecamatan Kebumen dan Bojongsari Kecamatan Alian.

\section{B. Pengumpulan Kansei Words}

Pengumpulan kansei words dilakukan dengan penyebaran kuesioner terbuka untuk menggali kata-kata kansei dari beberapa sumber yang dapat menggambarkan suatu produk peci, salah satunya dengan wawancara kepada responden laki-laki dewasa usia 15 tahun ke atas. Dari hasil observasi kata-kata kansei didapatkan 38 kansei words yang kemudian disederhanakan lagi bila kata-kata tersebut mempunyai kesamaan arti dan makna. Pada tabel 1. telah didapatkan hasil dari kuesioner terbuka yang kemudian dipilah lagi untuk mendapatkan hasil kansei word.

Tabel 1. Hasil kuesioner terbuka

\begin{tabular}{|l|c|l|c|}
\hline NO & Kansei Words & NO & Kansei Words \\
\hline 1 & Awet & 20 & Modern \\
2 & Water resistant & 21 & Menarik \\
3 & Nyaman & 22 & Tidak kasar \\
4 & Polos & 23 & Inovatif \\
5 & Lembut & 24 & Modis \\
6 & Bermotif menarik & 25 & Percaya diri \\
7 & Motif batik & 26 & Cerah \\
8 & Tidak kaku & 27 & Tidak formal \\
9 & Adem dipakai & 28 & Unik \\
10 & Sistem ventilasi bagus & 29 & Tidak sesak \\
11 & Ringan & 30 & Tidak gatal \\
12 & Kuat & 31 & Lembut \\
13 & Fleksibel & 32 & Mudah digunakan \\
14 & Tahan lama & 33 & Tidak panas \\
15 & Halus & 34 & Gaya \\
16 & Tidak panas & 35 & Percaya diri \\
17 & Murah & 36 & Resmi \\
18 & Simpel & 37 & Laki \\
19 & Enteng & 38 & Eksentrik \\
\hline
\end{tabular}

Dari ke 38 kata-kata hasil observasi diambil kata yang benar-benar mewakili kansei words, dan didapatkan 10 kata kansei sebagaimana pada tabel 2:

Tabel 2. Hasil kansei words setelah dipilah

\begin{tabular}{|c|c|}
\hline NO & Kansei Words \\
\hline $\mathbf{1}$ & Nyaman \\
$\mathbf{2}$ & Lembut \\
$\mathbf{3}$ & Adem(dingin) \\
$\mathbf{4}$ & Kuat \\
$\mathbf{5}$ & Halus \\
$\mathbf{6}$ & Simpel \\
\hline
\end{tabular}




\begin{tabular}{|c|c|}
\hline NO & Kansei Words \\
\hline $\mathbf{7}$ & Enteng \\
$\mathbf{8}$ & Modis \\
$\mathbf{9}$ & Cerah \\
$\mathbf{1 0}$ & Unik \\
\hline
\end{tabular}

\section{Pengumpulan Sampel Produk}

Pengumpulan sampel produk atau desain sampling dilakukan dengan mengambil sampel produk di beberapa pasar yang berada di sekitar Kebumen dan juga langsung mengambil di pengrajin yang berada di Desa Bandung Kecamatan Kebumen dan Desa Bojongsari Kecamatan Alian.

Dari hasil observasi produk didapatkan lima buah sampel yang terdiri dari berbagai jenis peci baik dari segi motif, warna, bahan dan lain-lain. Berikut beberapa sampel produk peci:

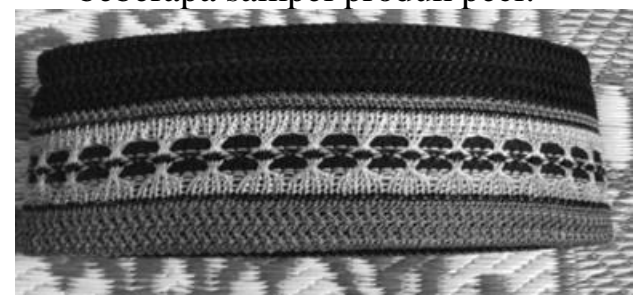

Gambar 1. Spesifikasi sampel peci 1

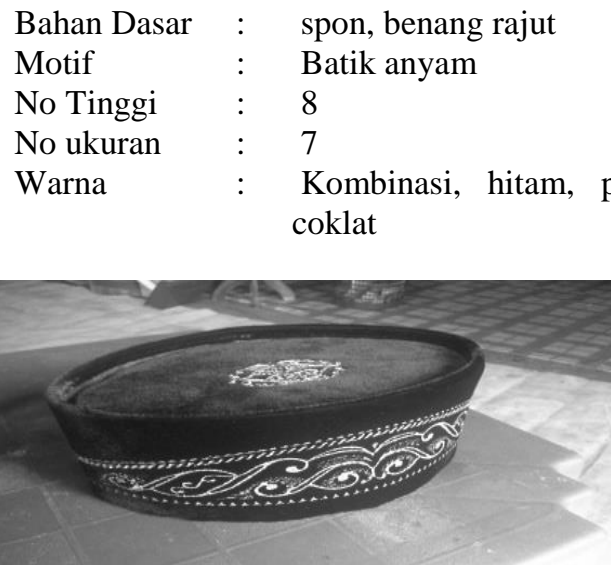

Gambar 3. Spesifikasi sampel peci 3

$\begin{array}{lll}\text { Bahan dasar } & : & \text { Karton,bludru 1 } \\ \text { Motif } & : & \text { Batik bordir } \\ \text { No Tinggi } & : & 9 \\ \text { No ukuran } & : & 7 \\ \text { Warna } & : & \text { Kombinasi kunig, putih }\end{array}$

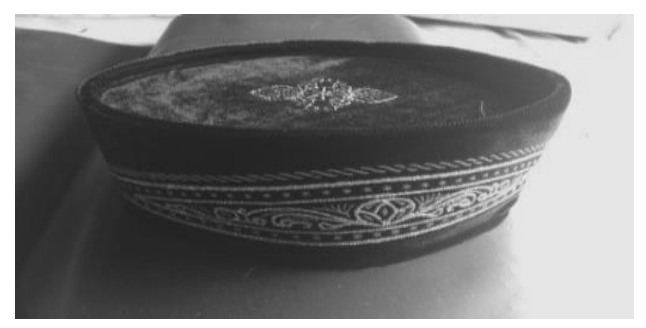

Gambar 5. Spesifikasi sampel peci 5:

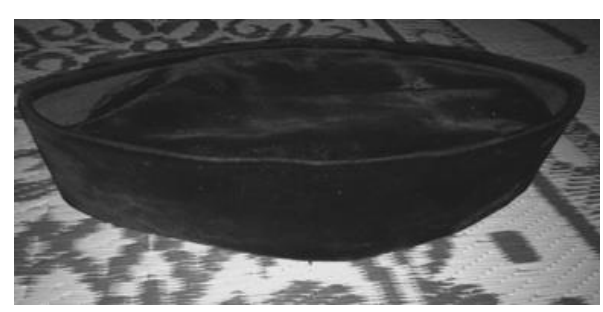

Gambar 2. Spesifikasi sampel peci 2

$\begin{array}{lll}\text { Bahan dasar } & : & \text { Karton, bludru,kualitas2 } \\ \text { Motif } & : & \text { Polos } \\ \text { No tinggi } & : & 7 \\ \text { No Ukuran } & : & 6 \\ \text { Warna } & : & \text { Hitam polos }\end{array}$

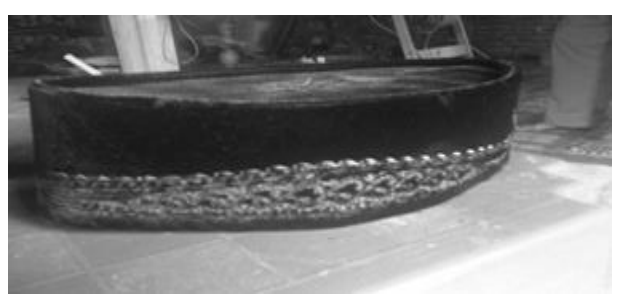

Gambar 4. Spesifikasi sampel peci 4

Bahan Dasar : Karton, Bludru kualitas1

Motif : Batik cap

No tinggi : 9

No ukuran : 8

Warna : Kombinasi, hitam, biru 


\begin{tabular}{|c|c|}
\hline Bahan Dasar & Karton, Bludru kualitas 1 \\
\hline Motif & Batik cap \\
\hline No tinggi & 9 \\
\hline No ukuran & 8 \\
\hline Warna & Kombinasi hitam kuning \\
\hline
\end{tabular}

\section{Penyusunan Kuesioner Semantik Diferensial}

Kuesioner semantik diferensial dibuat untuk mendapatkan penilaian terhadap seberapa penting kansei words dirasakan oleh pengguna ketika memakai peci, dengan menggunakan 5 skala penilaian.

Pada kuesioner ini responden akan melakukan penilaian kepada beberapa sampel dengan memberikan skor terhadap kansei words yang telah dipasangkan dengan kata lawannya.

a. Uji Validitas

Uji validitas bertujuan untuk mengetahui valid tidaknya suatu kuesioner. Suatu kuesioner dikatakan valid jika pertanyaan dalam kuesioner mampu mengungkapkan suatu yang akan diukur. Dari hasil uji validitas yang dilakukan pada 50 responden terdapat 9 variabel yang tidak valid karena mempunyai nilai $r$ hitung $<$ daripada $r$ tabel. Dan variabel yang tidak valid tidak akan dimasukan ke perhitungan selanjutnya, berikut ini hasil dari uji validitas.

Tabel 3. Hasil Uji Validitas

\begin{tabular}{|l|l|l|l|l|l|}
\hline Kansei & Sampel 1 & Sampel 2 & Sampel 3 & Sampel 4 & Sampel 5 \\
words & & & & & \\
\hline Nyaman & - & $\sqrt{ }$ & - & - & $\sqrt{ }$ \\
Lembut & $\sqrt{ }$ & $\sqrt{ }$ & - & - & $\sqrt{ }$ \\
Adem & - & $\sqrt{ }$ & - & - & - \\
Kuat & $\sqrt{ }$ & - & $\sqrt{ }$ & $\sqrt{ }$ & - \\
Halus & $\sqrt{ }$ & $\sqrt{ }$ & $\sqrt{ }$ & - & $\sqrt{ }$ \\
Simpel & $\sqrt{ }$ & - & $\sqrt{ }$ & $\sqrt{ }$ \\
Enteng & $\sqrt{ }$ & $\sqrt{ }$ & - & $\sqrt{ }$ & - \\
Modis & $\sqrt{ }$ & $\sqrt{ }$ & - & $\sqrt{ }$ & $\sqrt{ }$ \\
Cerah & $\sqrt{ }$ & $\sqrt{ }$ & $\sqrt{ }$ & $\sqrt{ }$ & $\sqrt{ }$ \\
Unik & - & $\sqrt{ }$ & - & $\sqrt{ }$ & - \\
\hline
\end{tabular}

b. Uji Reliabilitas

Reliabilitas merupakan keajegan, konsistensi, stabilitas. Uji reliabilitas digunakan untuk mengetahui bahwa alat ukur yang digunakan dapat dipercaya untuk pengumpulan data. Suatu variabel dikatakan reliabel jika nilai alpha cronbachnya $\geq 0.244$ untuk responden berjumlah 65 . Dari hasil uji reliabilitas yang dilakukan masing-masing nilai reliabilitas $>0.244$ maka dari hasil ini dapat disimpulkan bahwa semua variabel pada kuesioner tersebut dikatakan reliabel. Berikut ini hasil uji reliabilitas.

Tabel 4. Hasil uji Reliabilitas sampel produk peci

\begin{tabular}{|c|c|}
\hline No sampel & Cronbach's Alpha \\
\hline Sampel 1 & 0.666 \\
Sampel 2 & 0.592 \\
Sampel 3 & 0.499 \\
Sampel 4 & 0.536 \\
Sampel 5 & 0.579 \\
\hline
\end{tabular}

Pada tabel 4. di atas menunjukkan bahwa hasilnya reliabel. 


\section{E. Penentuan Parameter Desain}

\section{Analisis conjoint, Perumusan Masalah}

Analisis konjoin digunakan untuk menentukan tingkat relatif berdasarkan persepsi pelanggan yang dibawa oleh suatu produk tertentu dan nilai kegunaan muncul dari atribut-atribut produk terkait. Untuk melakukan proses analisis conjoint langkah pertama adalah merumuskan masalah, merumuskan masalah dalam conjoint dengan cara mencari antribut dan tarafnya, atribut kita dapat dari hasil penyebaran kuesioner sebelumnya, berikut ini hasil dari pembentukan taraf atribut.

Tabel 5. Hasil Pembentukan Taraf Atribut

\begin{tabular}{|l|c|l|}
\hline \multicolumn{1}{|c|}{ Atribut } & Taraf & \multicolumn{1}{|c|}{ Keterangan } \\
\hline Jenis & 1 & Sampel 1 \\
& 2 & Sampel 2 \\
& 3 & Sampel 3 \\
& 4 & Sampel 4 \\
Harga & 5 & Sampel 5 \\
& 1 & Rp 25.000 \\
Bahan & 2 & Rp 35.000 \\
& 3 & Rp 50.000 \\
& 1 & Bludru kualitas 1 \\
& 2 & Bludru kualitas 2 \\
Motif & 3 & Spon \\
& 4 & Bludru kualitas 3 \\
& 1 & Batik bordir \\
& 2 & Batik cap \\
& 3 & Polos \\
\hline
\end{tabular}

2. Analisis conjoint Penentuan Stimuli Produk

Stimuli merupakan kombinasi dari berbagai atribut. Penentuan stimuli produk dilakukan untuk dijadikan kuesioner conjoint. Dalam pembentukan stimuli produk dapat dilakukan dengan dua cara yaitu dengan menggunakan manual dan dengan bantuan olah data SPSS 21. Dalam proses ini pembentukanya menggunakan bantuan SPSS dengan menggunakan perintah editor syntax, setelah 25 stimuli produk terbentuk selanjutnya. dijadikan kuesioner stimuli produk.

Tabel 6. Hasil Stimuli Produk

\begin{tabular}{|l|l|l|l|l|}
\hline STIMULI & \multicolumn{1}{|c|}{ JENIS } & HARGA & \multicolumn{1}{|c|}{ BAHAN } & \multicolumn{1}{|c|}{ MOTIF } \\
\hline 1 & PECI 3 & Rp 35.000 & BLUDRU 1 & KAIN ANYAM \\
2 & PECI 3 & Rp 25.000 & BLUDRU 1 & POLOS \\
3 & PECI 5 & Rp 35.000 & BLUDRU 3 & KAIN ANYAM \\
4 & PECI 2 & Rp 35.000 & SPON & POLOS \\
5 & PECI 3 & Rp 50.000 & BLUDRU 3 & BATIK BORDIR \\
6 & PECI 2 & Rp 25.000 & BLUDRU 2 & BATIK CAP \\
7 & PECI 3 & Rp 25.000 & BLUDRU 2 & BATIK BORDIR \\
8 & PECI 4 & Rp 25.000 & SPON & BATIK BORDIR \\
9 & PECI 2 & Rp 25.000 & BLUDRU 1 & BATIK BORDIR \\
10 & PECI 5 & Rp 35.000 & BLUDRU 1 & BATIK BORDIR \\
11 & PECI 2 & Rp 50.000 & BLUDRU 1 & BATIK BORDIR \\
12 & PECI 1 & Rp 25.000 & BLUDRU 3 & POLOS \\
13 & PECI 1 & Rp 50.000 & SPON & KAIN ANYAM \\
14 & PECI 2 & Rp 35.000 & BLUDRU 1 & BATIK BORDIR \\
15 & PECI 5 & Rp 25.000 & SPON & BATIK BORDIR \\
16 & PECI 1 & Rp 35.000 & BLUDRU 2 & BATIK CAP \\
17 & PECI 1 & Rp 35.000 & BLUDRU 1 & BATIK BORDIR \\
\hline
\end{tabular}




\begin{tabular}{|l|l|l|l|l|}
\hline STIMULI & JENIS & \multicolumn{1}{|c|}{ HARGA } & \multicolumn{1}{|c|}{ BAHAN } & \multicolumn{1}{|c|}{ MOTIF } \\
\hline 18 & PECI 5 & Rp 25.000 & BLUDRU 1 & BATIK CAP \\
19 & PECI 5 & Rp 50.000 & BLUDRU 2 & POLOS \\
20 & PECI 3 & Rp 35.000 & SPON & BATIK CAP \\
21 & PECI 4 & Rp 35.000 & BLUDRU 1 & POLOS \\
22 & PECI 1 & Rp 25.000 & BLUDRU 1 & BATIK BORDIR \\
23 & PECI 4 & Rp 25.000 & BLUDRU 2 & BATIK ANYAM \\
24 & PECI 4 & Rp 50.000 & BLUDRU 1 & BATIK CAP \\
25 & PECI 4 & Rp 35.000 & BLUDRU 3 & BATIK BORDIR \\
\hline
\end{tabular}

\section{Uji Validitas Reliabilitas Stimuli Produk}

Setelah diberi skala kemudian stimuli produk dilakukan uji validitas reliabilitas untuk mengetahui valid tidaknya stimuli yang akan diteliti, dan untuk melakukan tahap selanjutnya, Berikut merupakan hasil uji validitas dan reliabilitas stimuli produk.

Tabel 7. Hasil uji Validitas kuesioner stimuli produk.

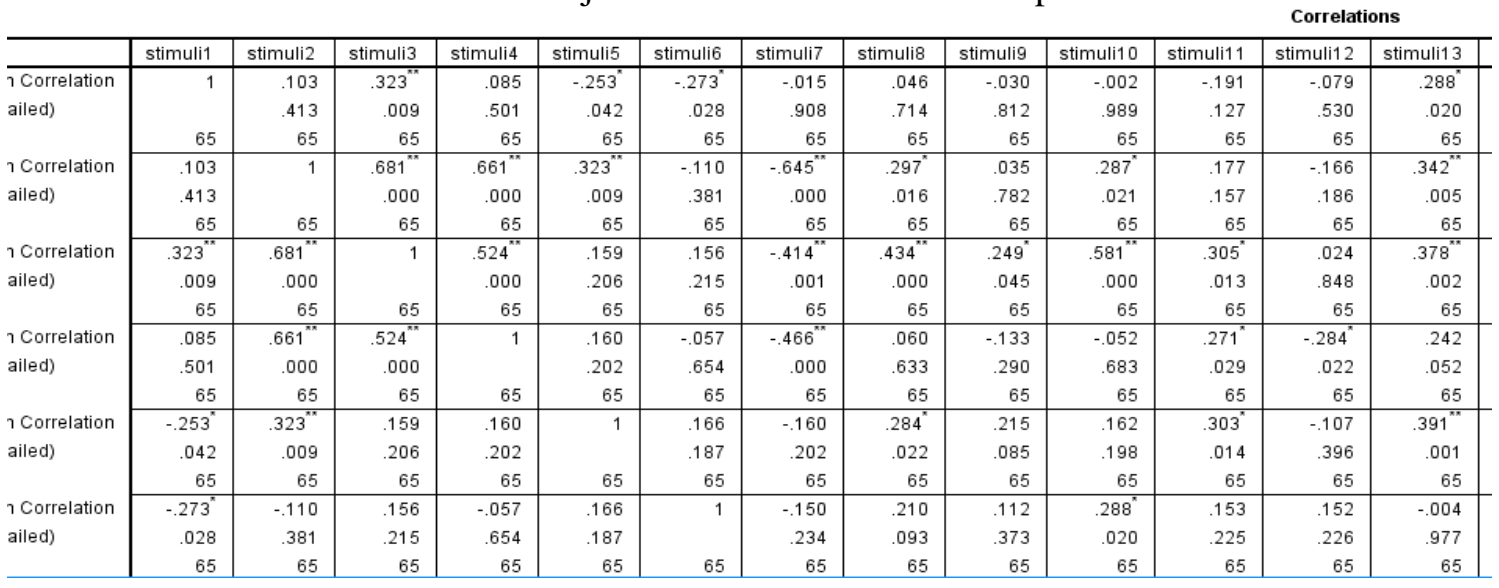

Hasil dari perhitungan statistik menyatakan bahwa nilai alpha cronbach sebesar 0.683 dengan 65 responden sehingga dapat dikatakan hasil tersebut reliabel.

\section{Preferensi Masyarakat Tentang Produk Peci yang Diinginkan}

Preferensi masyarakat tentang produk peci yang diinginkan diambil dari data kuesioner stimuli produk, diperoleh hasil sebagai berikut ini.

1. Jenis Peci

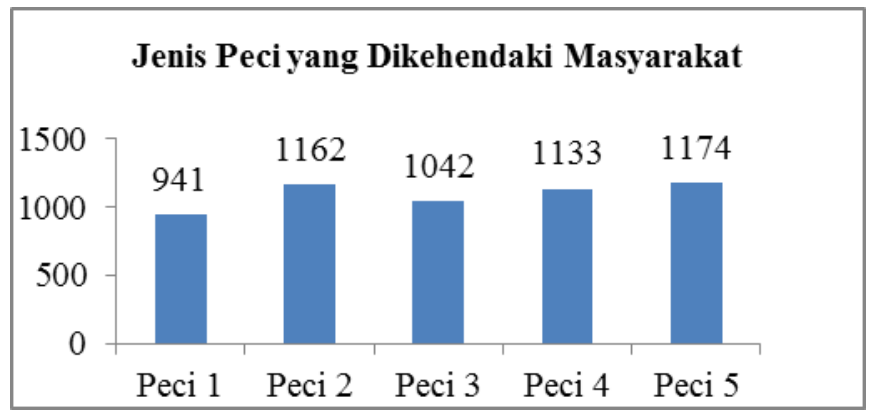

Gambar 6. Jenis Peci yang paling diminati masyarakat

Berdasarkan gambar 6 di atas dapat diketahui bahwa jenis peci yang dikehendaki masyarakat adalah Jenis peci no 5 dengan total jumlah skor 1174. 
2. Harga Peci

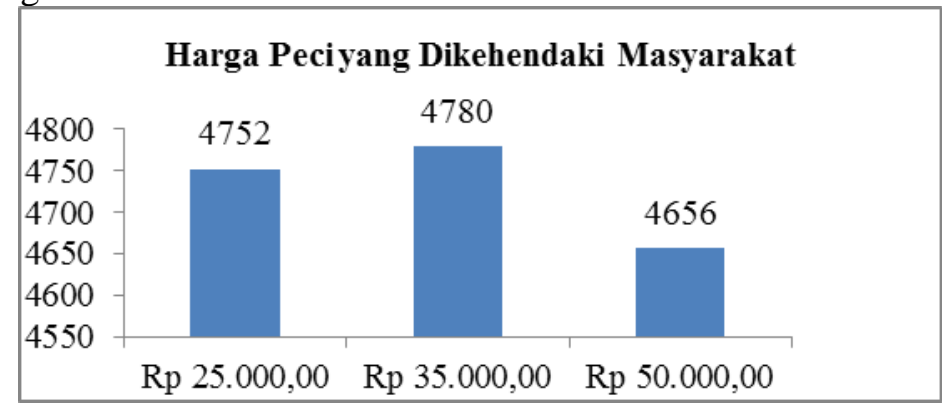

Gambar 7. Harga peci yang paling diminati masyarakat

Berdasarkan gambar 7. di atas peci yang paling diminati masyarakat seharga Rp 35.000,00 dengan jumlah skor 4780.

3. Bahan Peci

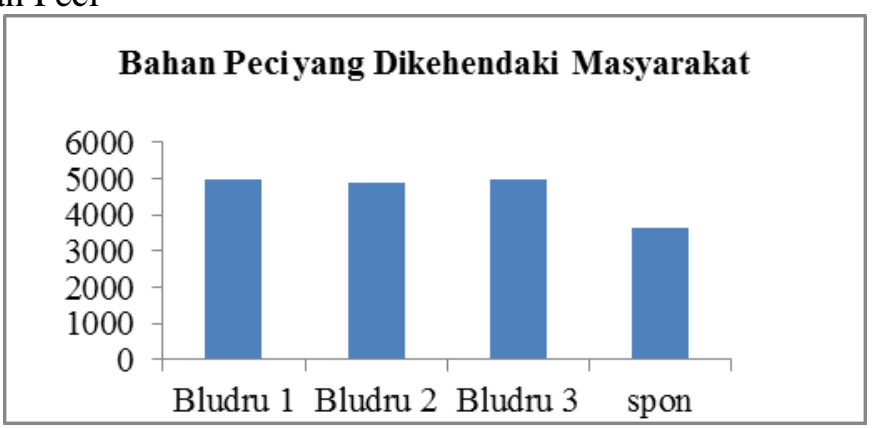

Gambar 8. Hasil analisis Bahan peci yang dikehendaki masyarakat

Dari gambar 8. diatas dapat dilihat bahwa bahan peci dengan memakai bludru1 merupakan bahan yang dikehendaki masyarakat dengan jumlah skor 4975.

4. Motif Peci

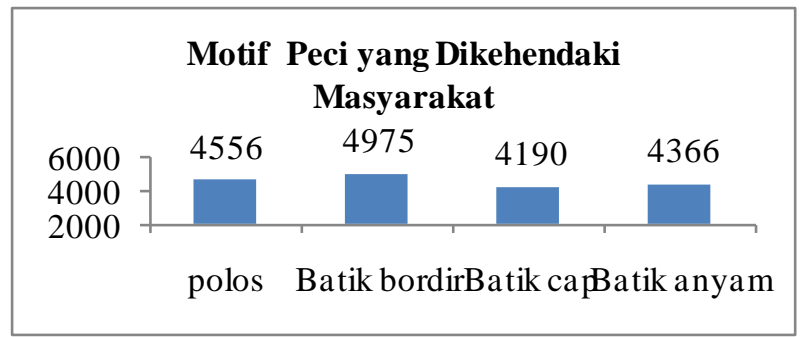

Gambar 9. Hasil analisis motif peci yang dikehendaki masyarakat

Berdasarkan Gambar 9. Di atas dapat kita ketahui bahwa motif batik bordir merupakan motif yang paling diminati masyarakat dengan jumlah skor 4975. 


\section{F. Hasil Rancangan Produk 1. Pemetaan Desain Parameter}

Tabel 8. Hasil Pemetaan Desain Parameter

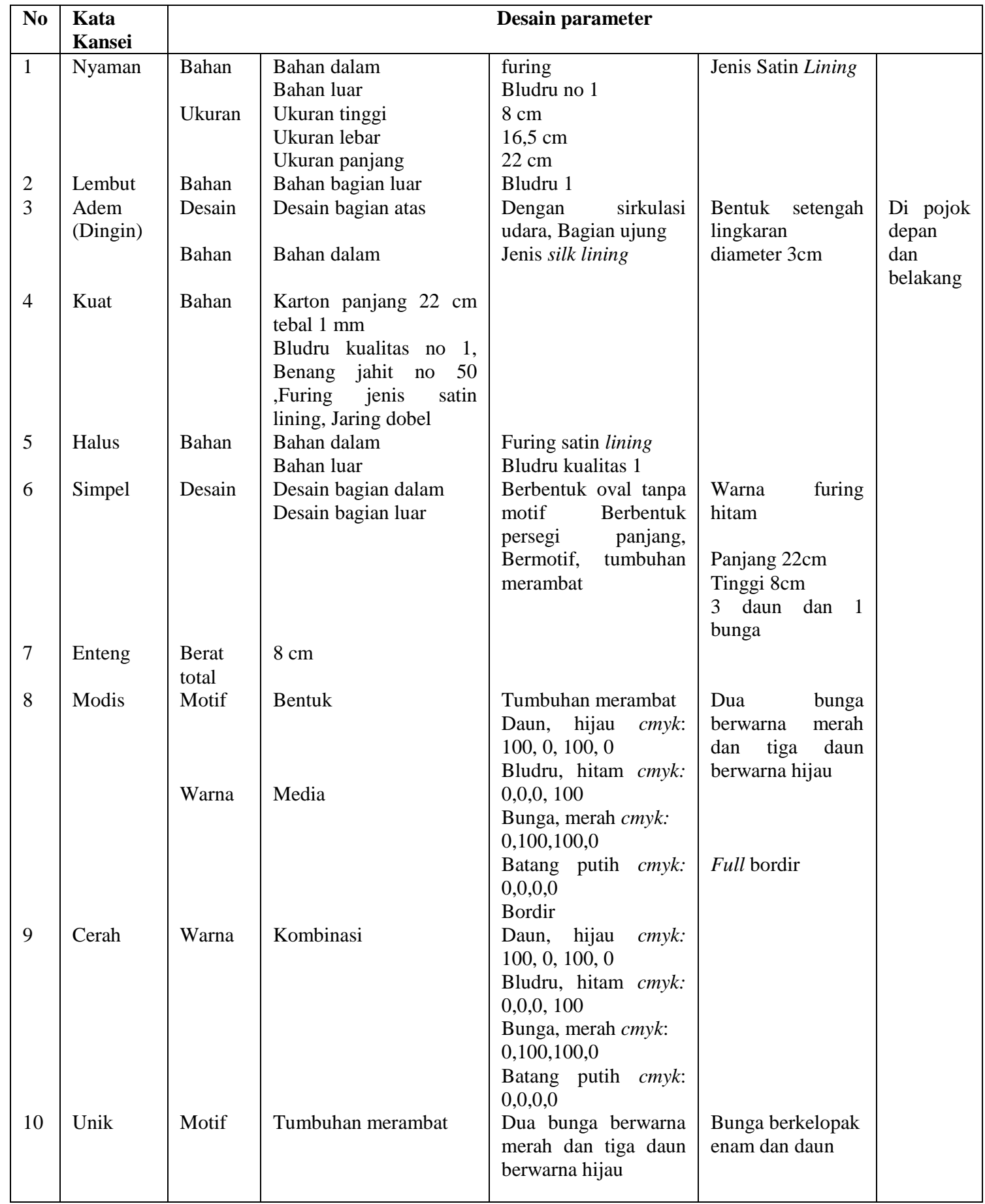

Keterangan: cmyk merupakan kepanjangan dari cyan magenta yellow-black, adalah proses pencampuran pigmen yang lazim digunakan percetakan.

\section{Hasil Rancangan Produk}

Setelah selesai melakukan tahapan dalam kansei engineering dan diperoleh produk yang sesuai dengan keinginan konsumen langkah selanjutnya adalah melakukan rancangan produk. Rancangan produk dilakukan berdasarkan hasil 
dari tahapan kansei engineering seperti analisis conjoint dan juga diskusi dengan pengrajin untuk menghasilkan produk peci yang dikehendaki masyarakat. Berikut ini hasil rancangan produk yang telah diselesaikan

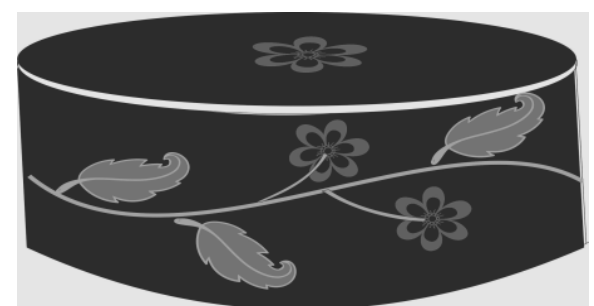

Gambar 10. Gambar Keseluruhan peci

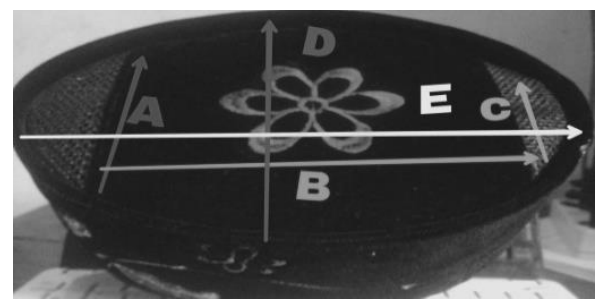

Gambar 11. Peci tampak atas

Keterangan:

a. Lebar bludru atas $9 \mathrm{~cm}$

b. Panjang bludru atas $15,5 \mathrm{~cm}$

c. Diameter jaring $8 \mathrm{~cm}$ Jari-jari peci $4 \mathrm{~cm}$

d. Lebar peci bagian atas $14,5 \mathrm{~cm}$

e. Panjang peci bagian atas $22,5 \mathrm{~cm}$

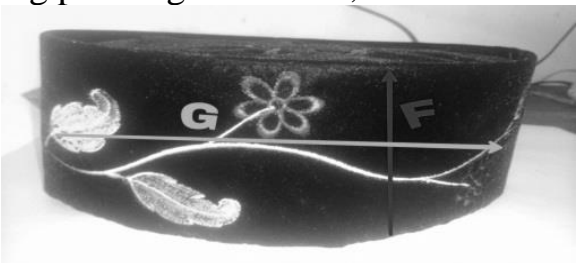

Gambar 12. Peci tampak samping

Keterangan:

f. Tinggi peci $8,5 \mathrm{~cm}$

g. Panjang peci sisi peci keseluruhan $58 \mathrm{~cm}$

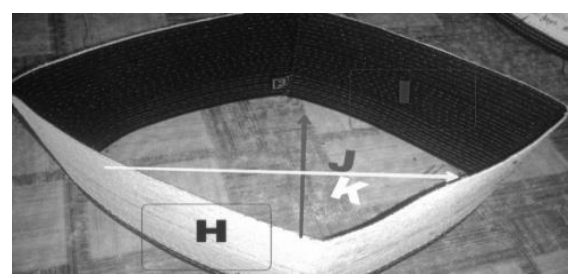

Gambar 13. Peci Bagian Dalam

Keterangan:

h. Karton tebal $1 \mathrm{~mm}$ lebar 7,5 $\mathrm{cm}$ panjang sisi keseluruhan $55 \mathrm{~cm}$

i. Furing tinggi $7 \mathrm{~cm}$ panjang sisi keseluruhan $53 \mathrm{~cm}$

j. Lebar peci bagian dalam $13,7 \mathrm{~cm}$

k. Panjang peci bagian dalam $21 \mathrm{~cm}$ 


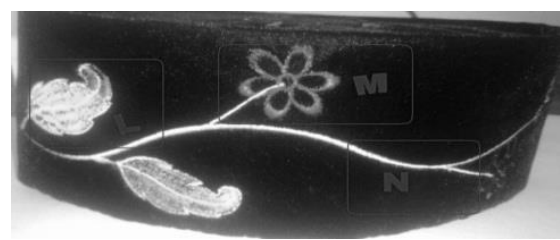

Gambar 14. Motif Bagian samping peci

\section{Keterangan:}

1. Daun berwarna hijau cmyk:100,0100,0 full bordir, Lebar daun 2 $\mathrm{cm}$, panjang daun $5 \mathrm{~cm}$, Benang bordir polyester no 50, Tangkai berwarna putih cmyk:0,0,0,0 dengan panjang $2,5 \mathrm{~cm}$

m. Bunga bermahkota 6 berbentuk oval dan berwarna merah cmyk: $0,100,100,0$ bordir pinggir diameter $0.5 \mathrm{~cm}$ dan panjang $1 \mathrm{~cm}$, Diameter keseluruhan 2,5 cm, Diameter lingkaran dalam $0,5 \mathrm{~cm}$, Panjang per mahkota berbentuk oval $1 \mathrm{~cm}$, Tangkai berwarna putih cmyk:0,0,0,0 dengan panjang $2,5 \mathrm{~cm}$

n. Batang berwarna putih cmyk: 0,0,0,0 lebar full bordir Panjang 35 $\mathrm{cm}$, Lebar $4 \mathrm{~mm}$

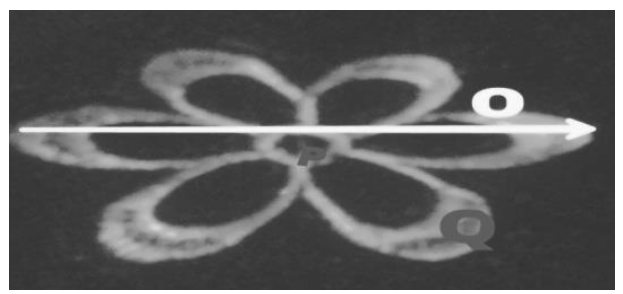

Gambar 15. Motif Bagian atas peci

Keterangan:

Warna merah cmyk:0,100,100,0

o. Diameter keseluruhan $7 \mathrm{~cm}$

p. Diameter lingkaran dalam $1 \mathrm{~cm}$

q. Panjang mahkota berbentuk oval $3 \mathrm{~cm}$

r. Lebar mahkota berbentuk oval $1,5 \mathrm{~cm}$

s. Lebar bordir

\section{G. Uji Homogenitas}

Setelah dilakukan beberapa pengujian pada metode kansei engineering, selanjutnya dilakukan validasi dari produk peci yang telah dirancang, pada penelitian ini validasi dilakukan dengan uji marginal homogeneity.

Hipotesis :

Ho = Tidak terdapat perbedaan/perubahan pendapat responden terhadap produk peci yang telah didesain dan sebelum didesain.

$\mathrm{H}_{1}=$ Terdapat perbedaan/perubahan pendapat responden terhadap desain peci sebelum dan sesudah dibuat.

Kriteria uji :

Tolak Hipotesis nol (Ho) jika nilai signifikansi p-value $(<0,05)$

Berikut hasil pengujian marginal homogeneity menggunakan SPSS: 
Tabel 9. Hasil Uji marginal homogenity

\begin{tabular}{|l|r|}
\hline \multicolumn{2}{|c|}{ Marginal Homogeneity Test } \\
\hline \multicolumn{1}{|c|}{$\begin{array}{c}\text { Sebelum \& } \\
\text { Sesudah }\end{array}$} \\
\hline Distinct Values & 8 \\
Off-Diagonal Cases & 43 \\
Observed MH Statistic & 259.000 \\
Mean MH Statistic & 314.000 \\
Std. Deviation of MH Statistic & 9.301 \\
Std. MH Statistic & -5.914 \\
Asymp. Sig. (2-tailed) & .000 \\
\hline
\end{tabular}

Dari kelima sampel peci yang dibandingkan dipilih sampel nomor lima karena sudah mewakili keinginan responden. Dengan hasil peci yang telah didesain diperoleh hasil sebagaimana tertera pada Tabel 11. Marginal Homogeneity test nilai p-value uji Marginal Homogeneity test sebesar 0,00 $(<0,05)$ maka hipotesis nol (Ho) ditolak. Jadi kesimpulannya terdapat perbedaan/perubahan pendapat responden terhadap produk peci yang telah didesain.

\section{KESIMPULAN DAN SARAN}

\section{A. Kesimpulan}

Kesimpulan dari penelitian ini adalah :

1. Hasil preferensi pengguna terhadap desain peci yang diinginkan didapatkan, sampel peci nomor 5, bermotif batik bordir dengan $\mathrm{Rp} 35.000,00$ dan berbahan bludru kualitas 1.

2. Merekomendasikan desain peci yang telah didapatkan yaitu peci dengan bahan bludru kualitas 1 bermotif batik bordir tumbuhan merambat berdaun tiga, berkelopak enam hijau cmyk: 100, 0, 100, 0 Bludru, hitam cmyk: 0,0,0, 100 Bunga, merah cmyk: 0,100,100,0. Bersirkulasi udara dibagian atas dengan berbentuk setengah lingkaran, dan menggunkan kertas karton dibagian dalam dibungkus dengan furing satin lining.

\section{B. Saran}

1. Peci yang telah didesain agar bisa diproduksi dan dipasarkan oleh pengrajin untuk memenuhi kebutuhan peci saat ini.

2. Perlu dilakukan penelitian lanjutan dengan menggunakan metode kansei yang lain (Kansei Engineering system KES, Jenis Kansei Engineering Hybrid, Virtual kansei Engineering ) untuk membandingkan hasil yang telah didapatkan pada penelitian ini.

3. Penelitian selanjutnya diharapkan lebih banyak dalam menggali kata-kata kansei supaya hasilnya lebih maksimal.

4. Penelitian lebih diperluas lagi tidak hanya bagi masyarakat Kebumen tetapi juga untuk masyarakat umum seluruh Indonesia.

\section{DAFTAR PUSTAKA}

[1] Ceicalia, Dedy Suryadi, Yoan Brachmantiyoko, 2012, Perancangan Ulang Kemasan Produk Shampo dengan Mempertimbangkan Emosi Konsumen Berdasarkan Metode Kansei Engineering, diunduh pada Juli 2015, pukul 10.30 WIB. http://ejurnal. itenas.ac.id/index.php/rekarupa/article/view/486

[2] Damasio, 1999, A Review Essay on Antonio Damasio's The Feeling of What Happens: Body and Emotion in the Making of Consciousness, http://www. theassc. org/files/assc/2468.pdf, diunduh pada Juni 2015 Pukul 12.21 WIB. 
[3] Ghozali, Imam, 2009, Aplikasi Analisis Multivariat dengan Program SPSS, ed. 4, Universitas Diponegoro, Semarang.

[4] Guna, Wakhid Agung Ady 2011, Pengembangan Desain Kursi Roda Khususnya pada Lansia Berdasarkan Citra (image) Produk dengan Metode Kansei Engineering , Jurusan Teknik Industri Fakultas Teknik Universitas Sebelas Maret Surakarta 2011, digilib.uns.ac.id

[5] Haryono, Mei dan Bariyah, Choirul, 2014, Perancangan Konsep Produk Alas Kaki dengan Menggunakan Integrasi Metode Kansei Engineering dan Model: Jurnal Ilmiah Teknik Industri, Vol. 13, No. 1, Juni 2014, journals.ums.ac.id/ index.php/ jiti/article/download diunduh pada pada Juli 2015 pukul 11.20 WIB.

[6] Indrawan Lucky Setia, 2011, Aplikasi Metode Kansei Engineering pada Produk Multitool, Tersedia di http://eprints.undip.ac.id/33144/ diunduh pada juli 2015 pukul 15.34 WIB.

[7] Lokman, Mohd Anitawati 2011, Design \& Emotion: The Kansei Engineering Method, The Malaysian Journal of Computing (MJoC), Vol. 1 No. 1, ISSN 22317473, UPENA, Malaysia. Universiti Teknologi MARA (UiTM) Malaysia Vol. 1, issue, 2011

[8] Matondang, Zulkifli, 2012, Pengujian Homogenitas Varians Data, https://www. scribd.com/doc/.../9-Pengujian-Homogenitas diunduh pada 4 Juli 2016 pukul 14.00 WIB.

[9] Mujib Moh. Fatkhul, 2010, Analisis Faktor-Faktor Yang Berpengaruh Secara Langsung dan Tidak Langsung Terhadap Kinerja Usaha Kecil \& Menengah (UKM), http://eprints.undip.ac.id/26942/1/Jurnal_Analisis_Faktor-

Faktor_Yang_Berpengaruh_Secara_Langsung_Dan_Tidak_Langsung_Terhadap_Kin erj.pdf diunduh Juni 2016 pukul 11.30 WIB

[10] Muntahanah Siti, Tjahjani Murdijaningsih, 2014 Tinjauan Kinerja Manajerial dari Aspek Keuangan pada Usaha Kecil Menengah (UKM) Home Industri Peci di Bandung Kebumen, Fakultas Ekonomi Universitas Wijaya Kususma Purwokerto, https://publikasiilmiah.ums.ac.id/bitstream/handle/11617/4656/33- diunduh pada Juni 2016 pukul $11.20 \mathrm{WIB}$

[11] Nagamachi, 1995, A New Ergonomic Consumer-Oriented Technology for Product Development, https://scholar. google.de/citations? user=bvb4BhwAAAAJ\&hl=de diunduh pada Juni 2015 pukul 14.22 WIB

[12] Nagamachi, 2011, Advances in Ergonomics in Manufacturing, https://books. google.co.id/books di unduh pada Desember 2015 pukul $10.30 \mathrm{WIB}$

[13] Srikandi, Margareta, Johan K Runtuk, dan Lusia Permata Sari H. 2012, Rekayasa Desain Batik Tulis Jetis Sidoarjo Melalui Implementasi Metode Kansei Engineering Jurnal GEMA AKTUALITA, Vol. 1 No. 1

[14] Vonny Johan Setiaries dkk, 2012, Pengembangan Sistem Evaluasi Desain Produk Berbasis Rotan dengan Pendekatan Rekayasa Kansei dan Association Rules System, http://repository.unri.ac.id/xmlui/handle/123456789/7452

AGROINTEK Volume 6, No.2 Agustus 2012, diunduh pada Juni 2015, pukul 13,33 WIB,

[15] Wahyuning, Sri Caecilia, Arie Desrianty, Rika Rahmawati, 2011, Studi Rancangan Konsep Brassiere Melalui Pendekatan Nilai Emosi dan Perasaan Menggunakan Kansei Engineering Method, Jurnal Itenas Rekarupa, Institut Teknologi Nasional No.1 Vol.1 Januari - Maret 2011. 